\title{
Pulmonary manifestations of chronic liver disease: a comprehensive review
}

\section{Stergios Soulaidopoulos ${ }^{a}$, loannis Goulis ${ }^{b}$, Evangelos Cholongitas ${ }^{c}$}

Hippokration General Hospital, National and Kapodistrian University of Athens; Hippokration General Hospital, Medical School of Aristotle University of Thessaloniki, Thessaloniki, Greece; Laiko General Hospital, Medical School of National and Kapodistrian University of Athens, Athens, Greece

Abstract

\section{Introduction}

Pulmonary vascular complications, namely hepatopulmonary syndrome (HPS) and porto-pulmonary hypertension $(\mathrm{PoPH})$, are not infrequent in patients with chronic liver disease and/or portal hypertension ( $\mathrm{PH})$, being now recognized as significant comorbidities affecting functional

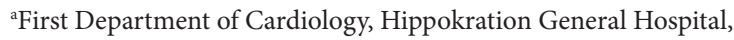
National and Kapodistrian University of Athens (Stergios Soulaidopoulos); ${ }^{b}$ Fourth Department of Internal Medicine, Hippokration General Hospital, Medical School of Aristotle University of Thessaloniki (Ioannis Goulis); 'First Department of Internal Medicine, Laiko General Hospital, Medical School of National and Kapodistrian University of Athens (Evangelos Cholongitas), Greece

Conflict of Interest: None

Correspondence to: Stergios Soulaidopoulos, Amisou 110, 17124

Athens, Greece, e-mail: soulaidopoulos@hotmail.com

Received 22 August 2019; accepted 6 December 2019; published online 27 March 2020

DOI: https://doi.org/10.20524/aog.2020.0474 status as well as pre- and post-transplantation survival. These 2 major pulmonary manifestations differ in prevalence, underlying pathophysiology, clinical course and their impact on survival; hence, they require prompt distinction and therapeutic management. The main pathogenetic mechanism in HPS is the dilatation of pulmonary vasculature, which leads to impaired gas exchange and progressive hypoxemia due to intrapulmonary shunting [1]. In contrast, obstruction to arterial flow in the pulmonary vasculature in the presence of increased pulmonary vascular resistance following excessive pulmonary vasoconstriction defines $\mathrm{PoPH}$ and leads to an increase in right ventricle afterload and ultimately to right heart failure [2]. Both HPS and PoPH may present as dyspnea, though it is not rare for them to show no specific clinical symptoms [3] (Fig. 1). Before the establishment of their diagnosis, exclusion of other etiologies of lung disease, as well as the presence and impact of other manifestations of advanced liver disease, such as hepatic hydrothorax $(\mathrm{HH})$, ascites and muscle wasting, on pulmonary function must be evaluated [4]. More particularly, the development of pleural effusions in the context of decompensated cirrhosis, known as $\mathrm{HH}$, may cause severe respiratory dysfunction resistant to treatment. 
Since liver transplantation (LT) stands at the top of the therapeutic pyramid for liver cirrhosis, it is crucial to understand interactive pathogenetic mechanisms, establish efficient screening methods and discuss current pre- and postoperative management strategies and dilemmas for patients with HPS, PoPH and $\mathrm{HH}$ in order to achieve optimal survival rates among LT candidates.

\section{HPS}

\section{Definition and diagnostic criteria}

HPS is characterized by an impairment of arterial oxygenation in the setting of chronic liver disease, $\mathrm{PH}$ or congenital portosystemic shunts, as a result of localized or diffuse intrapulmonary vascular dilatations and arteriovenous communications leading to right-to-left intrapulmonary shunt $[5,6]$. The above elements form the revised diagnostic criteria for HPS, which can be summarized in the triad of chronic liver disease, gas exchange abnormalities, and evidence of intrapulmonary vasodilatation [1] (Table 1). A recently accepted

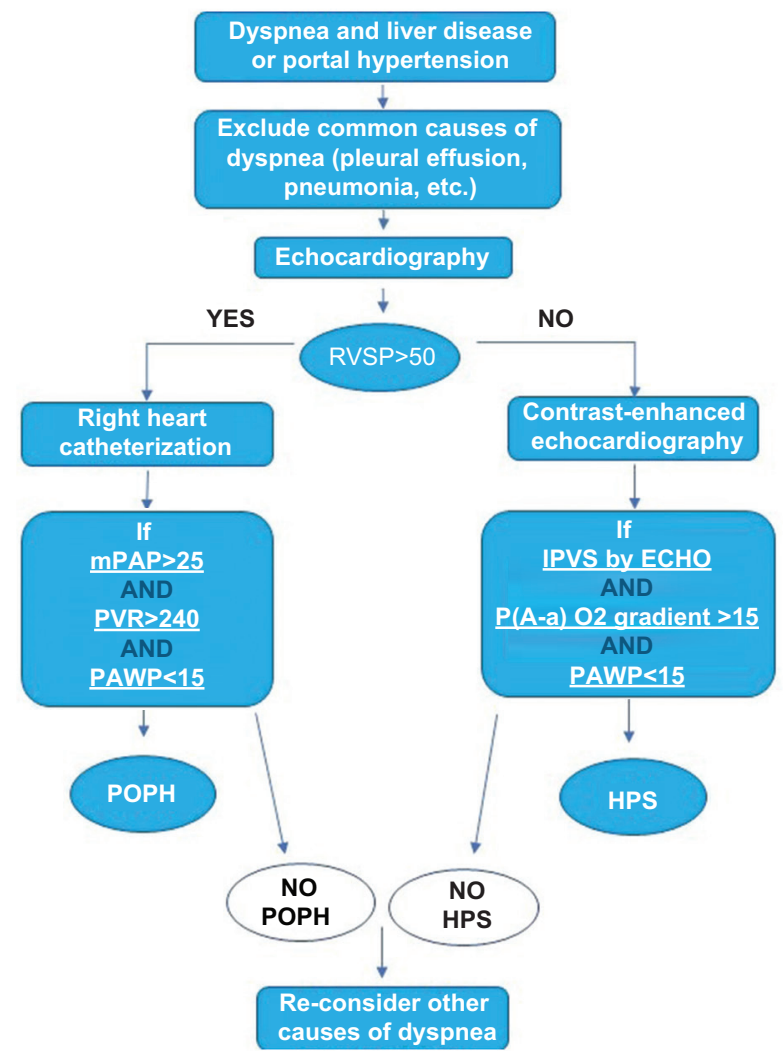

Figure 1 Diagnostic algorithm for patients with chronic liver disease and dyspnea

RVSP, right ventricular systolic pressure; $m P A P$, mean pulmonary arterial pressure; $P V R$, pulmonary vascular resistance; $P A W P$, pulmonary artery wedge pressure; IPVS, intrapulmonary vascular shunting; ECHO, echocardiography; $P(A-a) O 2$, Alveolar-arterial oxygen pressure gradient; $\mathrm{POPH}$, portopulmonary hypertension; HPS, hepatopulmonary syndrome definition of arterial deoxygenation specifies an elevated alveolararterial oxygen gradient $(>15 \mathrm{mmHg}$ or $>20 \mathrm{mmHg}$ for age $>65$ years), rather than the use of partial oxygen pressure $\left(\mathrm{PaO}_{2}\right)$ alone [7]. Obtaining blood gas measurements with the patient in the supine rather than the upright position is suggested as a more sensitive method to detect HPS [8]. Interestingly, HPS can develop in acute or chronic liver disease, $\mathrm{PH}$ without liver disease, Wilson's disease and $\alpha 1$ antitrypsin deficiency [9].

\section{Epidemiology}

The fact that different criteria and not uniform protocols have been used for the diagnosis of HPS has led to a wide range of prevalence rates among different studies. These discrepancies are mainly attributed to the varying alveolar-arterial gradient and $\mathrm{PaO}_{2}$ thresholds used for the detection of impaired arterial oxygenation [10]. As a result, the prevalence of HPS is estimated to range from $4-47 \%$, with most recent studies, using the diagnostic criteria proposed by the European Respiratory Society Task Force in 2004 [3], reporting an average of 30\% in patients with end-stage liver disease [11-13]. The use of the alveolar-arterial gradient as a more sensitive marker of oxygenation abnormalities, combined with the establishment of screening protocols in transplantation candidates, led to higher HPS diagnostic rates, even among asymptomatic patients. Notably, the detection of intrapulmonary vascular dilatations and arteriovenous communications, which can be found in $13-80 \%$ of end-stage liver disease patients, must not be not be confused with HPS, as it is not enough to set the diagnosis when not followed by impaired oxygenation [14].

\section{Pathophysiology}

Ventilation-perfusion mismatch represents the leading cause of hypoxemia in HPS. This is the result of a decrease in

Table 1 Clinical classification of pulmonary hypertension

\begin{tabular}{|c|c|}
\hline Group 1 & $\begin{array}{l}\text { Pulmonary arterial hypertension (PAH) } \\
\text { - Idiopathic PAH } \\
\text { - Heritable PAH } \\
\text { - Drug and toxin induced } \\
\text { - Associated with other conditions } \\
\text { - Connective tissue disease } 0 \\
\text { - Human immunodeficiency virus (HIV) } \\
\text { - Portal hypertension } \\
\text { - Congenital heart disease } \\
\text { - Schistosomiasis }\end{array}$ \\
\hline Group 1' & $\begin{array}{l}\text { - Pulmonary veno-occlusive disease and/or } \\
\text { pulmonary capillary hemangiomatosis }\end{array}$ \\
\hline Group 1” & - Persistent pulmonary hypertension of the newborn \\
\hline Group 2 & Secondary to left heart disease \\
\hline Group 3 & Secondary to lung disease and/or hypoxia \\
\hline Group 4 & Chronic thromboembolic pulmonary hypertension \\
\hline Group 5 & $\begin{array}{l}\text { Unclear multifactorial mechanisms (hematologic, } \\
\text { systemic, metabolic, other) }\end{array}$ \\
\hline
\end{tabular}


the transit time of red blood cells, combined with an impaired oxygen diffusing capacity as well as direct right-to-left blood shunting [15]. Pulmonary vascular remodeling, characterized by dilatation of pre-capillary and capillary vessels, as well as arteriovenous communications, leads to an increase in pulmonary blood flow, with a large amount of blood passing through the pulmonary circulation without completing gas exchange, while ventilation remains unchanged [16]. This phenomenon is aggravated by the hyperdynamic circulation characterizing end-stage liver disease [17]. Intrapulmonary vasodilatation creates a functional right-to-left shunt. Oxygen diffusion capacity is disturbed, as oxygen molecules need to travel a longer distance in less time in order to reach red blood cells in the center of the dilated capillaries [18]. An increase in pulmonary capillary wall thickness in patients with HPS has also been observed, explaining the association of HPS with abnormal values of carbon monoxide diffusing capacity [19]. Pleural and pulmonary arteriovenous communications, mainly attributed to neoangiogenesis, constitute "anatomic" shunts that allow the direct passage of venous, unoxygenated blood into the central circulation, boosting arterial hypoxemia [20]. The severity of hypoxemia seems to be related to the extent of pulmonary vasodilatation and arteriovenous shunting. A rise in the partial pressure of inspired oxygen, by administration of $100 \%$ oxygen, may dramatically improve HPS hypoxemia by overcoming the diffusing limitation when capillary dilatation predominates, while no effect may be seen in HPS characterized by excessive right-to-left communication [21].

Liver cirrhosis and $\mathrm{PH}$ are characterized by a disturbance in the production of vasoactive molecules, with an imbalance between vasodilators and vasoconstrictors that leads to marked splanchnic vasodilatation [22]. More specifically, as far as HPS is concerned, it seems that overproduction of nitric oxide (NO) and carbon monoxide (CO) plays a central role in the development of intrapulmonary vasodilatation. Elevated levels of exhaled NO have been recorded in cirrhotic patients with HPS, and tend to normalize after LT $[23,24]$. Evidence from animal experimental models suggests that hepatic production and release of endothelin-1, and its binding to the pulmonary receptor ET-1B, triggers the activation of endothelial and inducible NO synthase (eNOS and iNOS), resulting in NO overproduction [25]. Massive accumulation of pulmonary intravascular macrophages, boosted by both endothelin-1 production and the endotoxemia characterizing liver cirrhosis, also contributes to the activation of pulmonary e- and iNOS [2628]. In addition, bacterial translocation in the lungs and $\mathrm{NO}$ activation trigger the expression of heme oxygenase, which leads to higher CO production via heme degradation [29].

Pulmonary angiogenesis, mainly promoted by vascular endothelial growth factor (VEGF), is the second mechanism that completes the interpretation of HPS pathogenesis. Early histological findings have demonstrated the presence of an increased arterial density in the alveolar wall of cirrhotic patients who have impaired oxygenation [20]. A genetic background, with polymorphisms in genes that regulate angiogenesis, seems to modulate vascular growth and development in HPS [30]. The accumulation of CD68+ macrophages in the lungs, in combination with circulating inflammatory chemokines, such as tumor necrosis factor (TNF)- $\alpha$, trigger the activation of VEGF angiogenic signaling pathways, as has been shown in experimental animal models [31]. These pathways may also be responsible for the recently demonstrated associations between HPS and hepatocellular carcinoma, also characterized by excessive VEGF production and angiogenesis [32]. Thus, it is not surprising that anti-VEGF treatment with sorafenib improves HPS hypoxia and intrapulmonary shunting in cirrhotic rats [33]. Nevertheless, in a recent randomized controlled study, no clinical improvement was achieved after a 3-month treatment with sorafenib in patients with HPS, despite a reduction in circulating levels of angiogenic markers [34]. Finally, intrahepatic vascular changes characterized by an enhanced obstruction of intrahepatic portal branches have also been associated with HPS development $[35,36]$.

\section{Classification and clinical presentation}

HPS is classified into 4 severity stages according to arterial $\mathrm{PaO}_{2}$ in blood gas analysis with the patient breathing ambient air: mild ( $\mathrm{PaO}_{2} \geq 80 \mathrm{mmHg}$ ), moderate $\left(\mathrm{PaO}_{2} \geq 60\right.$ and $<80 \mathrm{mmHg}$ ), severe $\left(\mathrm{PaO}_{2} \geq 50\right.$ to $\left.<60 \mathrm{mmHg}\right)$, and very severe $\left(\mathrm{PaO}_{2}<50\right.$ $\mathrm{mmHg}$ ) [37] (Table 2). Available data suggest a predominance of mild and moderate stage HPS cases, while no correlations between the severity of liver disease and the severity or even presence of HPS have been established so far [38].

Progressive dyspnea accompanied by arterial hypoxemia is the most common characteristic of HPS [39]. A special form of dyspnea, called platypnea, is pathognomonic for HPS and refers to the paradoxical worsening of dyspnea when the patient shifts from a supine to an upright position [40]. An increase in blood perfusion of the basis of the lungs in the upright position leads to a higher intrapulmonary shunt, confirmed as a decrease in $\mathrm{PaO}_{2}$ in the arterial blood of $\geq 5 \%$ (or $\geq 4 \mathrm{mmHg}$ ), a phenomenon called orthodeoxia [41]. Physical examination may reveal cyanosis, fatigue, digital clubbing, and spider nevi, with the latter showing a positive predictive value of $75 \%$ in HPS diagnosis [42]. Moreover, patients with HPS have a worse functional status, according to the New York Heart Association

Table 2 Diagnostic criteria for hepatopulmonary syndrome and porto-pulmonary hypertension

\begin{tabular}{cc}
\hline Hepatopulmonary syndrome & $\begin{array}{l}\text { Porto-pulmonary } \\
\text { hypertension }\end{array}$ \\
\hline $\begin{array}{l}\text { 1. Portal hypertension with or } \\
\text { without cirrhotic liver disease }\end{array}$ & $\begin{array}{l}\text { 1. Presence of portal } \\
\text { hypertension }\end{array}$ \\
$\begin{array}{c}\text { 2. Arterial hypoxemia } \\
\text { 2. Presence of pulmonary } \\
\text { arterial hypertension }\end{array}$ \\
greater than $15 \mathrm{mmHg}$ & - Mean pulmonary \\
3. Pulmonary vascular dilatation & arterial pressure \\
demonstrated by & higher than $25 \mathrm{mmHg}$ \\
- "Positive" contrast-enhanced & - Pulmonary artery \\
transthoracic echocardiography, or & wedge pressure lower \\
- Abnormal brain uptake ( $>6 \%)$ & than 15 mmHg \\
after technetium-99m & - Pulmonary vascular \\
macroaggregated albumin & resistance greater \\
(99mTcMAA) lung perfusion & than 240 dyn.sec.cm ${ }^{-5}$ \\
\hline
\end{tabular}


classification, compared with patients without HPS [43]. Not infrequently, none of these clinical features are present and HPS remains asymptomatic, especially in patients with mild impairment of oxygenation.

\section{Diagnosis}

The triad of liver disease, impaired arterial oxygenation and the presence of intrapulmonary vascular dilatations characterize HPS [3] (Table 1). Pulse oximetry and, more specifically, the difference in oxygen saturation $\left(\mathrm{SpO}_{2}\right)$ between the supine and upright positions, may be used as the initial step to identify patients with impaired oxygenation and possible HPS [44]. The cutoff value of $96 \%$ previously proposed for $\mathrm{SpO}_{2}$, below which a further evaluation with blood gas analysis should be considered [45], was recently found to be inadequate regarding its sensitivity (29\%) for HPS discrimination [46]. In this latter study, the authors found that the optimal cutoff value of $\mathrm{SpO}_{2}$ for HPS detection was $97 \%$, which still had a sensitivity of only 56\% (95\% confidence interval [CI] 45$67 \%)$ and a negative predictive value of $83 \%$ (95\%CI 78-88\%) (i.e., $17 \%$ of patients with $\mathrm{SpO}_{2} \geq 96 \%$ had HPS), showing that pulse oximetry performed no better than chance in the discrimination of HPS among LT candidates. Hence, the authors concluded that the use of contrast-enhanced echocardiography and arterial blood gas sampling, performed either simultaneously or in consecutive steps, constitutes the most efficient screening for HPS [46]. However, with HPS patients showing a decline in $\mathrm{SpO}_{2}$ over time, not seen in non-HPS patients, either with or without intrapulmonary vasodilatation, pulse oximetry measurements may be a useful tool for monitoring LT candidates for the development of HPS [47]. In those LT candidates with a baseline $\mathrm{SpO}_{2}>96 \%$ and a decline of $\geq 2 \%$ in SpO2 over time, a repeat of blood gas analysis could identify either the development of HPS or a worsening of the HPS severity class, prompting management decisions regarding model for end-stage liver disease (MELD) exception and prioritization for transplantation.

Contrast-enhanced transthoracic echocardiography with agitated saline has now been established as the gold-standard method for the detection of pulmonary vascular dilatations [48]. It involves the peripheral intravenous administration of agitated saline during a 4-chamber echocardiographic study. Normal saline agitation produces microbubbles $>10 \mu \mathrm{m}$ in diameter, normally captured in the pulmonary circulation and absorbed by the alveoli-being less than $8 \mu \mathrm{m}$ in diameter, they cannot pass through normal capillaries. However, intrapulmonary vascular dilatation in HPS allows the passage of these microbubbles to the left cardiac chambers through the pulmonary circulation. The test is considered positive and indicative of intrapulmonary vasodilatation when left atrial opacification with microbubbles occurs between the fourth and sixth cardiac cycle after the completion of right atrial filling. Left atrial opacification within less than 3 cardiac cycles is not diagnostic and may be indicative of intracardiac shunting [49]. Pulmonary transit time, derived from pulmonary angiography, can be used in such cases as an alternative to echocardiography for the detection of intrapulmonary vascular dilatations [50]. A grading system of intrapulmonary shunt has been proposed based on contrast opacification of the left chambers and the number of bubbles bypassing into the left ventricle in one still frame [51-53]. According to this classification, the severity of intrapulmonary shunting can be graded as stage 1 (<30 microbubbles), 2 (30-100 microbubbles), or 3 (>100 microbubbles). Notably, left atrial enlargement $(\geq 50 \mathrm{~mL})$ was suggested as a strong echocardiographic predictor of HPS in patients with liver cirrhosis (area under the receiver operating characteristic curve: 0.903 , sensitivity $86.3 \%$, specificity 81.2\%) [54].

Lung nuclear perfusion scanning with technetium-99m macroaggregated albumin is another reliable method for the detection of intrapulmonary vasodilatation [55]. The macroaggregated albumin particles, $20-90 \mathrm{~mm}$ in size, can only pass through the pulmonary vascular bed in the presence of vascular dilatations. Hence, their detection in extrapulmonary organs, such as the brain, implies intrapulmonary vascular communications [56]. The method allows a quantification of the intrapulmonary shunting, but it is less sensitive than contrast-enhanced echocardiography and cannot distinguish intrapulmonary from intracardiac shunting [57].

\section{Treatment and prognosis}

While great progress has been recorded regarding our comprehension of HPS pathogenesis, promising pharmaceutical treatments targeting specific pathogenetic pathways have so far failed to show encouraging results [58]. Anti-angiogenetic factors, such as somatostatin analogs and sorafenib, showed no improvement of hypoxemia in HPS patients $[59,60]$. Restricting NO-mediated vasodilatation with methylene blue and the TNF- $\alpha$ inhibitor pentoxifylline also had no significant clinical impact on HPS progression. The antidiabetic agents metformin and pioglitazone improve intrapulmonary shunts, but not hypoxia, in biliary cirrhotic rats with HPS, highlighting once again the multifactorial contributions to HPS pathogenesis $[61,62]$. More encouraging results were recently obtained from the inhibition of placental growth factor, a proangiogenic molecule selectively involved in pathological angiogenesis, which improved experimental HPS in mice $[63,64]$.

Transjugular intrahepatic portosystemic shunting performed in some cases with severe HPS showed no clear benefit $[65,66]$. Coil embolization may improve the persistent hypoxemia of HPS, either before or after LT, in the presence of discrete arteriovenous communications [67].

LT constitutes for the moment the only effective treatment that modifies the natural history of HPS, with resolution of gas exchange abnormalities after 6-12 months [68]. A 5-year survival rate of $76 \%$, similar to that of cirrhotic patients without HPS undergoing LT has been reported [69]. Pre- and posttransplantation survival was also not significantly different between HPS and non-HPS patients in one study that enrolled 316 cirrhotic patients [70]. In contrast, higher 6-month postoperative mortality rates were found in HPS compared 
to non-HPS patients ( $33 \%$ vs. $9.25 \%, \mathrm{P}=0.0012$ ) among 90 patients prospectively evaluated after LT [71].

A pre-transplantation room-air $\mathrm{PaO}_{2} \leq 44.0 \mathrm{~mm} \mathrm{Hg}$ was demonstrated as the most important predictor of posttransplantation mortality (hazard ratio 1.58, 95\%CI 1.15-2.18) in a cohort of 973 LT candidates, highlighting the significance of preoperative HPS staging [72]. As a result of improvements in the perioperative management of patients with HPS, with regular assessment of the severity of hypoxemia and in-time LT prior to further worsening of hypoxemia, current data suggest that long-term survival after LT is no longer associated with $\mathrm{PaO}_{2}$ levels at the time of HPS diagnosis [73].

Taking all this together, the clinical practice guidelines of the European Association for the Study of the Liver (EASL) suggest that patients with $\mathrm{PaO}_{2}<60 \mathrm{mmHg}$ should be evaluated for LT [Level of evidence II-2 (based on case cohort and case control analytical studies); Grade of recommendations 1 (strong recommendation)], while a regular 6-month arterial blood gas analysis is recommended to prioritize HPS patients for LT before $\mathrm{PaO}_{2}$ levels decrease below $50 \mathrm{mmHg}$ [74]. In line with EASL, the American Association for the Study of Liver Diseases (AASLD) recommends pulse oximetry screening for HPS among patients with liver disease (1-A), as well as expedited evaluation for LT in patients with severe HPS and increased mortality (1-B) [75]. The general consensus is that patients with HPS and severe hypoxemia should be prioritized for LT, regardless of the severity of their liver disease [76]. More specifically, standard exception points to the MELD score have been allocated by the United Network for Organ Sharing (UNOS) for patients with $\mathrm{HPS}$ and $\mathrm{PaO}_{2}$ lower than $60 \mathrm{mmHg}$ and no other clinically significant pulmonary condition [77]. The MELD exception for HPS starts at 22 points and is increased every 3 months if $\mathrm{PaO}_{2}$ remains under $60 \mathrm{mmHg}$. However, there is concern that the current exception policy might overprioritize waitlisted HPS patients, offering a survival advantage to HPS over non-HPS cirrhotic candidates, due to their greater chance of receiving a transplant; this highlights the need for future modification of the MELD exception policy [72].

\section{PoPH}

\section{Definition and diagnostic criteria}

$\mathrm{PoPH}$, a rare complication of end-stage liver disease, is defined as pulmonary arterial hypertension (PAH) in the setting of $\mathrm{PH}$, with or without liver disease, and is included in group I of the 2008 Dana Point classification of PH [78] (Table 3) Hence, it is characterized by elevated pulmonary artery pressure and increased pulmonary vascular resistance, as a result of a remodeling process of the pulmonary vasculature. The diagnosis of PoPH should be based on hemodynamic measurements obtained by right heart catheterization, where the following diagnostic criteria must be fulfilled: a mean pulmonary artery pressure (MPAP) $>25 \mathrm{mmHg}$, a pulmonary artery wedge pressure (PAWP) $\leq 15 \mathrm{mmHg}$, peripheral vascular resistance $(\mathrm{PVR})>240 \mathrm{dyn} \cdot \mathrm{sec} \cdot \mathrm{cm}^{-5}$ and transpulmonary
Table 3 Staging of hepatopulmonary syndrome and porto-pulmonary hypertension

\begin{tabular}{lll}
\hline Stage & $\begin{array}{l}\text { Hepatopulmonary } \\
\text { syndrome }\end{array}$ & $\begin{array}{l}\text { Portopulmonary } \\
\text { hypertension }\end{array}$ \\
\hline Mild & $\mathrm{PaO}_{2} \geq 80 \mathrm{mmHg}$ & MPAP: $25-35 \mathrm{mmHg}$ \\
Moderate & $\mathrm{PaO}_{2} \geq 60$ and $<80 \mathrm{mmHg}$ & MPAP: $35-45 \mathrm{mmHg}$ \\
Severe & $\mathrm{PaO}_{2} \geq 50$ to $<60 \mathrm{mmHg}$ & MPAP: $>45 \mathrm{mmHg}$ \\
Very severe & $\mathrm{PaO}_{2}<50 \mathrm{mmHg}$ & \\
\hline $\mathrm{PaO}_{2}$ Partial pressure of oxygen; $M P A P$, mean pulmonary artery pressure
\end{tabular}

gradient (TPG) $>12 \mathrm{mmHg}$ in the presence of clinical evidence of $\mathrm{PH}$ [79] (Table 1).

\section{Epidemiology}

In the majority of patients with $\mathrm{PoPH}$, end-stage liver disease with $\mathrm{PH}$ constitutes the primary disorder. However, $\mathrm{PoPH}$ has also been associated with $\mathrm{PH}$ without chronic liver disease, such as portal vein thrombosis [80]. Among patients with cirrhosis, prospective catheterization studies have demonstrated a prevalence of PoPH between 2\% and 5\% [81-83]. In the United Kingdom National PAH registry, the prevalence of PoPH was 0.85 cases per million [84]. It has been reported that female sex and autoimmune hepatitis are associated with an increased risk for PoPH [85]. Notably, similarly to what has been demonstrated for HPS, no association between the presence or severity of $\mathrm{PoPH}$ and the severity of liver disease, as assessed by MELD score, has been found [86]. Accounting for about $10 \%$ of patients with $\mathrm{PAH}$, $\mathrm{PoPH}$ remains a rather frequent type of group I PAH [87].

\section{Pathophysiology}

The histological background of $\mathrm{PoPH}$ seems to share common characteristics with idiopathic $\mathrm{PAH}$, being characterized by an obstruction of the pulmonary blood flow due to elevated vascular resistance [88]. However, although many theories exist, the exact pathogenetic pathways leading to PoPH still remain to be unraveled.

Histopathologically, PoPH is characterized by medial hypertrophy, due to periarteriolar smooth muscle cell proliferation and fibrosis, vasoconstriction and in situ thrombosis [18]. This seems to be the result of a dysregulation of neurohumoral substances, namely endothelin-1, thromboxane, interleukin-1, interleukin-6, and angiotensin, in the setting of impaired liver function [89]. In a context of a hyperdynamic circulatory state following splanchnic vasodilation and increased blood flow, a higher shear stress on the pulmonary endothelium as a result of turbulence in pulmonary blood flow may trigger vascular remodeling [90]. The presence of portosystemic shunts, as well as the inability of the liver to adequately filter blood arriving from the digestive tract, leads to a bypass of bacteria endotoxins and vasoactive 
substances into the pulmonary circulation, contributing to the pathogenesis of PoPH [91].

In contrast to what is known for HPS, a predominance of vasoconstrictors over vasodilators occurs in PoPH [92]. The pulmonary vasculature of patients with $\mathrm{PoPH}$ is exposed to higher levels of endothelin-1, a well-known systemic and pulmonary vasoactive peptide, compared to those in patients without PoPH $[89,93]$. While chronic liver disease is associated with elevated levels of circulating endothelin-1, directly produced by the cirrhotic liver, only a small percentage of cirrhotic patients develop PoPH, suggesting that more complex mechanisms, including genetic factors, are implicated in the pathogenesis of $\mathrm{PoPH}$.

\section{Classification and clinical presentation}

The most common presenting symptom of $\mathrm{PoPH}$ is dyspnea at rest or on exertion [94]. Not infrequently, and especially in the early stages, PoPH may remain asymptomatic and thus is not easily recognized, if there is a lack of high clinical suspicion and given the impaired mobility of cirrhotic patients. Clinical manifestations from the underlying liver disease and coexisting complications may cover or be confused with symptoms attributed to $\mathrm{PoPH}$, such as weakness, fatigue, hemoptysis, and orthopnea, which may be present in more advance stages of $\mathrm{PoPH}$ [95]. In the presence of dyspnea in patients with liver disease, HPS is always considered in the differential diagnosis and may be distinguished by the worsening of dyspnea in a standing position (platypnea). Physical findings include, besides signs of chronic liver disease, an accentuated and split second heart sound, right ventricular heave, right-sided S3 gallop and jugular venous distention, similarly to other forms of PAH.

Either measured in right heart catheterization or estimated echocardiographically, mean values of pulmonary artery pressure define the severity of $\mathrm{PoPH}$, classified as mild (MPAP $>25$ to $<35 \mathrm{mmHg}$ ), moderate (MPAP $\geq 35$ to $<45 \mathrm{mmHg}$ ), and severe (MPAP $\geq 45 \mathrm{mmHg}$ ) PoPH [96] (Table 2).

\section{Diagnosis}

Right heart catheterization (RHC) is the gold standard method for obtaining pulmonary hemodynamic measurements and confirming the diagnosis of PoPH. It is also recommended for the assessment of $\mathrm{PoPH}$ severity and the evaluation of treatment [97].

Nevertheless, echocardiography stands in the front line as a noninvasive, widely available screening tool for $\mathrm{PoPH}$ in patients with chronic liver disease. With the majority of patients with $\mathrm{PoPH}$ being asymptomatic, the latest European Respiratory Society/European Society of Cardiology (ERS/ ESC) guidelines suggest that an echocardiographic assessment for pulmonary hypertension should be performed in all LT candidates and symptomatic patients with cirrhosis and $\mathrm{PH}$ [98]. An echocardiographic estimation of right ventricular systolic pressure (RVSP) is possible by measuring the peak tricuspid regurgitation velocity (TRV) using the modified Bernoulli equation. RVSP and, consequently, pulmonary artery systolic pressure can then be calculated by adding the right atrial pressure estimated from inferior vena cava (IVC) respiratory variation $(0-5 \mathrm{mmHg}$ for IVC $\leq 21 \mathrm{~mm}$ and $>50 \%$ collapse with sniff, $5-10 \mathrm{mmHg}$ for IVC $\leq 21 \mathrm{~mm}$ with $<50 \%$ collapse with sniff or IVC $\geq 21 \mathrm{~mm}$ with $>50 \%$ collapse with sniff, IVC $>21$ $\mathrm{mmHg}$ and $<50 \%$ collapse with sniff) [99]. TRV values over $3.4 \mathrm{~m} / \mathrm{sec}$ or values between 2.9 and $3.4 \mathrm{~m} / \mathrm{sec}$ followed by echocardiographic signs of pulmonary hypertension provide a high probability for pulmonary hypertension [98].

The purpose of echocardiographic screening for the clinician is to decide which patients should be referred for further investigation with RHC. For the moment, there is no consensus as to the precise RVSP thresholds above which RHC should be performed. European Guidelines for Pulmonary Hypertension suggest the performance of RHC when there is a high probability for $\mathrm{PH}$, derived from echocardiographic measurements, clinical symptoms and concomitant risk factors [98]. Using a cutoff value of $50 \mathrm{mmHg}$ for RSVP has a sensitivity and specificity of $97 \%$ and $77 \%$, respectively, in identifying patients with moderate-to-severe PoPH [100]. An echocardiographically estimated RVSP $\geq 35 \mathrm{mmHg}$ typically implies a mean PAP more than $25 \mathrm{mmHg}$, while an RSVP $<30 \mathrm{mmHg}$ could be used to exclude PoPH [101]. Other echocardiographic signs of elevated pulmonary artery pressure include pulmonary artery and right atrial dilation and bulging of the septum into the left ventricular cavity, causing diastolic dysfunction [99]. Note that a hyperdynamic circulation state in chronic liver disease may lead to increased regurgitating flow in the tricuspid valve and overestimation of the probability of PoPH [102].

\section{Treatment and prognosis}

The treatment of PoPH follows more or less the general principles of $\mathrm{PAH}$ therapy, derived from a large number of prospective trials on pulmonary hypertension. However, such trials have always excluded patients with chronic liver disease and therefore specific guidelines on $\mathrm{PoPH}$ treatment are still lacking. For the first time, 13 patients with $\mathrm{PoPH}$ were included in the PATENT-1 trial with riociguat, a soluble guanylate-cyclase stimulator. Subgroup analysis was performed for patients with $\mathrm{PoPH}$ and showed that riociguat was well-tolerated and significantly improved World Health Organization functional class and the 6-min walking test after 12 weeks of treatment, while functional improvement was sustained for 2 years [103].

Regarding the efficacy and safety of the new PAH-targeted drugs, namely prostanoids, endothelin receptor antagonists and phosphodiesterase type 5 (PDE5) inhibitors, retrospective and observational data from case reports and case series encourage their administration in PoPH. Bosentan, a nonselective endothelin A and B receptor antagonist, has been found to be effective and well-tolerated in $\mathrm{PoPH}$, with considerable long- 
term results [104,105]. Small studies have shown improved hemodynamics and exercise tolerance after bosentan treatment, though a close monitoring of liver enzymes for the risk of drug hepatotoxicity is recommended [105]. Encouraging results were also shown in a small cohort consisting of 13 patients with Child-Pugh class A cirrhosis treated with ambrisentan, a selective endothelin A receptor antagonist with less hepatotoxicity compared to bosentan [106]. The results of a randomized, double-blind clinical study (PORTICO, NCT02382016), testing the effect of macitentan on PVR, are about to provide more evidence for the optimal management of patients with PoPH.

PDE5 inhibitors constitute another category of drugs extensively studied in PAH. They prevent the hydrolysis of cyclic guanosine monophosphate in endothelial cells, thus enhancing the vasodilating effects of NO [107]. Treatment of PoPH with sildenafil, the most representative drug of this category, alone or in combination with inhaled prostanoids, has led to a significant improvement in functional status and haemodynamics of LT candidates [108]. In this category of drugs belongs riociguat, whose beneficial effect in $\mathrm{PoPH}$ treatment has already been mentioned [101].

Epoprostenol is the most extensively studied drug among prostanoids, another category of $\mathrm{PAH}$-targeted therapies associated with pulmonary and systemic vasodilatation as well as inhibition of platelet aggregation. A short- and longterm improvement in pulmonary hemodynamics after epoprostenol administration has been reported in cirrhotic patients with PoPH, with a decrease in mean PAP and PVR and an increase in cardiac output [109]. With its immediate effect on pulmonary pressures, the use of intravenous and inhaled forms of epoprostenol has been adopted by many centers as a "bridge therapy" to LT, where an acute achievement of pulmonary hemodynamic targets prior to general anesthesia is needed [110]. Nevertheless, the long-term effect of epoprostenol on hepatic hemodynamics and symptoms of PoPH needs to be further evaluated [111]. Side-effects, such as thrombosis and infection, associated with the continuous transcatheter administration of intravenous epoprostenol, and the risk of thrombocytopenia, hypersplenism and systemic hypotension may discourage its use [112].

In the absence of specific guidelines, the treatment of PoPH needs to be individualized. Special characteristics and altered hemodynamics due to the underlying liver disease compared to $\mathrm{PAH}$ should be taken into consideration in the choice of the most appropriate medication [113]. Available data suggest that oral pulmonary vasoactive drugs are safe in cirrhotic patients and their positive effect on pulmonary hemodynamics is independent from the severity of the underlying liver disease, assessed by the Child-Pugh and MELD scores [114]. A meta-analysis of small studies demonstrated that the existing $\mathrm{PAH}$-specific therapy results in significant improvement in both pulmonary hemodynamics and exercise capacity in patients with PoPH [115]. Despite the similarities in the pathogenetic background of $\mathrm{PAH}$ and $\mathrm{PoPH}$, drugs with a crucial role in PAH management may have no place in PoPH. Calcium channel blockers are indicated in patients with $\mathrm{PAH}$ and a favorable vasodilator response to NO. Their vasodilating effect in splanchnic circulation may, on the other hand, lead to worsening of $\mathrm{PH}$ in patients with $\mathrm{PoPH}$; hence, they are not used in PoPH [116]. Anticoagulation, recommended in $\mathrm{PAH}$, is similarly not indicated in $\mathrm{PoPH}$ because of the increased bleeding risk associated with gastroesophageal varices, thrombocytopenia and coagulopathy due to liver dysfunction [117]. Despite their prophylactic effect on gastrointestinal bleeding in patients with liver disease and esophageal varices, the use of $\beta$-blockers in PoPH should generally be avoided as they are associated with a significant worsening of exercise capacity [118].

Transjugular intrahepatic portosystemic shunt (TIPS) creation is contraindicated in patients with severe PoPH. Mediated by both mechanical and neurohumoral factors, a rise in PVR constitutes the major hemodynamic alteration after TIPS placement [119].

In contrast to HPS, the presence of PoPH does not constitute an indication for LT. Despite adequate screening, careful patient selection and progress in PAH-specific therapies, the outcomes of LT in PoPH remain unpredictable [120]. Because of the increased intra- and perioperative mortality, the presence of moderate and severe PoPH is considered as a contraindication for LT, despite reports of cases with severe PoPH and successful LT after a good response to PAH treatment [121]. On the other hand, PoPH prognosis is very poor without LT, with 5 -year survival being less than $30 \%$ and a mean survival of 18 months $[122,123]$.

LT can, under proper patient selection, alter the natural history of the disease, with a reported 5-year survival of $67 \%$ [124]. What is known is that, if left untreated, PoPH is associated with catastrophic outcomes regarding post-LT survival [124]. Stabilization or reversibility of PoPH seems to be a realistic goal for the combination of $\mathrm{PAH}$-specific therapies and LT, with the reported survival rates reaching $77 \% 3$ years post-LT [125]. Nevertheless, data derived from a meta-analysis of the available studies suggest that, even after normalization of pulmonary hemodynamics before LT, PoPH confers a 1.59 (95\%CI1.26-2.01; P=0.0001) 1 -year mortality risk after LT [126]. It is not yet clear which patients are most likely to benefit from LT. A retrospective analysis of a French registry showed that $\mathrm{PH}$ was normalized in the majority $(60,9 \%)$ of patients undergoing LT, but those characteristics predicting a favorable outcome remain to be identified [127]. Both the severity of liver disease and $\mathrm{PoPH}$ are significantly associated with waitlist, but not post-transplant mortality [128]. Available data regarding the association between PAP and survival rates after LT in patients with PoPH show a $100 \%$ mortality rate for patients with mean PAP $>50 \mathrm{mmHg}, 50 \%$ for mean PAP $<50 \mathrm{mmHg}$ and $>35 \mathrm{mmHg}$, and $0 \%$ for mean PAP $<35 \mathrm{mmHg}$ [129]. The cause of death is acute right heart failure following preload increase, cytokine release and thrombus migration into the pulmonary circulation after reperfusion during LT and pulmonary infection $[124,130]$.

Taking all the previous data together, current guidelines from the International Liver Transplantation Society suggest that all LT candidates with a mean PAP $>35 \mathrm{mmHg}$ should be treated with PAH-targeted therapy to decrease mean PAP 
and PVR. More specifically, patients with a mean PAP of 35-45 $\mathrm{mmHg}$ and a PVR $>240 \mathrm{dyn} \cdot \mathrm{sec} \cdot \mathrm{cm}^{-5}$ should receive vasodilator therapy before transplantation and patients with mean PAP >45 mmHg should receive vasodilator therapy only. Those patients with a good clinical response to treatment achieving a mean PAP $<35 \mathrm{mmHg}$ should undergo LT [5]. Moreover, LT should be considered when mean PAP cannot be reduced below $35 \mathrm{mmHg}$ but there is normalization of PVR $\left(<240\right.$ dyn.sec $\left.\cdot \mathrm{cm}^{-5}\right)$ [5]. Note that a mean PAP greater than $50 \mathrm{mmHg}$ constitutes an absolute contraindication for LT, regardless of therapy. Whether $\mathrm{PoPH}$ responding to medical treatment alone should constitute an adequate indication for LT, independently from the MELD score, is a matter under discussion [131].

\section{HH}

\section{Definition and pathogenesis}

A plethora of disorders affecting different organ systems of the human body, including pleural, pulmonary and cardiac diseases, may lead to the development of a pleural effusion, characterized by the accumulation of fluid in the pleural cavity. Depending on the pathogenetic mechanism participating in its formation, a pleural effusion can be classified as transudative or exudative, with the criteria proposed by Light being the "gold standard" for their differentiation [132]. HH is a transudative pleural effusion that develops in a patient with liver cirrhosis in the absence of any other obvious cardiopulmonary or pleural pathology [133]. The most acceptable explanation for the development of $\mathrm{HH}$ is the direct passage of ascitic fluid into the pleural cavity through defects in the diaphragm as a result of the elevated abdominal pressure, compared to the negative intrathoracic pressure [134]. These defects, usually less than $1 \mathrm{~cm}$ in diameter, are mainly located on the right side of the diaphragmatic tendon. Hence, $\mathrm{HH}$ develops on the right side in $73-85 \%$ of cases, while $13-17 \%$ and $2-10 \%$ of cases present with a left-sided or a bilateral effusion, respectively [135]. The presence of a diaphragmatic defect can be confirmed with the injection of a technetium $99 \mathrm{~m}$-sulfur colloid or technetium 99m-human albumin into the peritoneal cavity and the detection of their passage into the pleural cavity [136]. The sum of positive abdominal pressure and negative intrathoracic pressure determines the flow of ascites towards the pleural cavity. Persistence of a $\mathrm{HH}$ without ascites may also be observed, if the rate of ascitic fluid passage to the pleural cavity equilibrates with the production of ascites [137].

\section{Diagnosis and clinical presentation}

Signs and symptoms of decompensated cirrhosis dominate the clinical presentation of patients with $\mathrm{HH}$. The severity of specific clinical manifestations associated with $\mathrm{HH}$, depends on the volume of the effusion, the rapidity of its development and cardiopulmonary comorbidities. Small effusions can be incidental findings during clinical examination or in chest imaging for other reasons, without causing considerable symptoms. Larger effusions are associated with pulmonary symptoms, ranging from shortness of breath and cough to dyspnea, hypoxemia and respiratory failure. Less frequently, decompensation of cirrhosis may primarily manifest as $\mathrm{HH}$ without clinically detected ascites. Among 77 hospitalized cirrhotic patients with $\mathrm{HH}$ included in a recent study, the majority $(73 \%)$ had a right sided pleural effusion, while $9 \%$ had no detectable ascites [138].

The diagnosis of $\mathrm{HH}$ is primarily based on clinical or imaging detection of a pleural effusion in the presence of chronic liver disease and $\mathrm{PH}$ and the exclusion of other causes of pleuritic fluid development or respiratory dysfunction. Thoracentesis followed by pleural fluid analysis is performed to identify the nature of the fluid and confirm the diagnosis. $\mathrm{HH}$ is a transudative effusion with characteristics similar to the ascetic fluid and a serum-to-pleural-albumin gradient $>1.1 \mathrm{mg} /$ $\mathrm{dL}$, although increased water absorption in the pleural cavity may be responsible for slightly higher total protein and albumin values in HH compared to the ascitic fluid [134]. Pleural fluid analysis should routinely include fluid total protein, albumin and lactate dehydrogenase levels, and cell count.

A polymorphonuclear (PMN) cell count $>250$ cells $/ \mathrm{mm}^{3}$ with a positive culture, or PMN cell count $>500$ cells $/ \mathrm{mm}^{3}$ with negative cultures and no evidence of pneumonia, are diagnostic for spontaneous bacterial empyema (SBEM), an infection of a preexisting hydrothorax [139]. The incidence of SBEM ranges between $13 \%$ and $16 \%$ and it should be routinely excluded in the presence of $\mathrm{HH}$ and distinguished from thoracic empyema secondary to a pulmonary infection [140]. Showing remarkable similarities to spontaneous bacterial peritonitis, it is believed that SBEM represents a bloodstream infection of the pleural fluid, following bacterial translocation and transient bacteremia characterizing dysregulation of theimmunesysteminlivercirrhosis. Escherichia coli, Streptococcus species, Enterococcus and Klebsiella are the most commonly detected causative microorganisms [141]. The clinical presentation of SBEM varies widely, from total absence of symptoms to local and systemic manifestations. The development of fever, thoracic pain, encephalopathy or unexplained worsening of renal function in a patient with $\mathrm{HH}$ should raise the suspicion for SBEM diagnosis.

\section{Management}

Treatment of $\mathrm{HH}$ is similar to the treatment of ascites and aims at the elimination of the fluid in both peritoneal and pleural cavities. Maintaining a negative sodium balance, through dietary sodium intake and diuretics, may lead to reduction in ascites and $\mathrm{HH}$ [142]. It is estimated that 20$25 \%$ of patients with $\mathrm{HH}$ do not respond to medical treatment and these are considered to have refractory $\mathrm{HH}$ [143]. LT constitutes the only effective treatment for refractory $\mathrm{HH}$, while other therapeutic choices aim to relieve the patient from symptoms and prevent pulmonary complications.

Thoracentesis is an effective procedure for the management of symptomatic patients with recurrent or refractory hydrothorax. 
Because of the recurrence of $\mathrm{HH}$, the benefits of thoracentesis are short-term and repetition of the procedure is often needed. Frequent performance of therapeutic thoracentesis increases the risk of complications from the procedure, including pneumothorax, hemothorax, vasovagal episodes, hemoptysis, air embolism, laceration of the liver or spleen, empyema, and subcutaneous emphysema [144]. Re-expansion pulmonary edema constitutes another rare complication of thoracentesis, which may develop after evacuation of a high pleural fluid volume over a short time and is associated with a history of pulmonary disease. Therefore, evacuation of more than $2000 \mathrm{~mL}$ of pleural fluid is not recommended. Moreover, massive fluid loss should be avoided because of the risk of acute renal injury [144].

TIPS is a percutaneous procedure that creates an anastomosis between portal and hepatic veins, thereby reducing portal pressure, showing beneficial effects in the management of $\mathrm{PH}$-related complications, such as ascites and $\mathrm{HH}$ [145]. With several non-controlled studies and case reports reporting rates up to $80 \%$, TIPS constitutes for the moment the standard of care for refractory HH [146]. However, TIPS is associated with serious complications, including portosystemic encephalopathy and worsening of liver function with high risk of decompensation in patients with stable liver cirrhosis. Therefore, TIPS may be considered for patients with preserved hepatic function and a Child-Pugh score $<10$ or MELD score $<15$ with no history of hepatic encephalopathy [147]. Although effective in selected patients, TIPS does not improve the overall prognosis of patients with end-stage liver disease [148].

Pleurodesis, performed with tetracycline, talc or bleomycin administered through a chest tube or by thoracoscopy, is another therapeutic option with less encouraging results, mainly reserved for the treatment of patients with refractory $\mathrm{HH}$ and absence of ascites [149]. Higher success rates have been reported with mechanical pleurodesis administered by videoassisted thoracoscopic surgery, especially when combined with closure of transdiaphragmatic fenestrations [150].

SBEM, when diagnosed, should be treated promptly with a third-generation cephalosporin (cefotaxime or ceftriaxone), also guided by the identification of the causative microorganism in pleural fluid cultures [151]. Carbapenems should be the treatment of choice in patients with nosocomial episodes, diabetes mellitus, and in those who have been treated with cephalosporins in the previous 3 months.

\section{Concluding remarks}

HPS, PoPH and HH represent pulmonary complications of chronic liver disease that alter the natural history, the prognosis and treatment options of the disease. Characterized by a variability in clinical presentation, with an absence of specific symptoms in the majority of cases, assiduous screening of LT candidates for HPS and PoPH is crucial for their optimal management and achievement of higher survival rates after LT. Severe HPS can be totally resolved with LT, and PAH-specific therapies in $\mathrm{PoPH}$ can significantly improve pulmonary hemodynamics and right ventricular function prior to LT.
The potential to cure and reverse HPS and PoPH, either with targeted therapy or with LT, creates an intriguing field for further clinical investigation.

\section{References}

1. Rodríguez-Roisin R, Krowka MJ. Hepatopulmonary syndrome-a liver-induced lung vascular disorder. N Engl J Med 2008;358:23782387.

2. Hervé $P$, Lebrec D, Brenot F, et al. Pulmonary vascular disorders in portal hypertension. Eur Respir J 1998;11:1153-1166.

3. Rodríguez-Roisin R, Krowka MJ, Hervé P, Fallon MB; ERS Task Force Pulmonary-Hepatic Vascular Disorders (PHD) Scientific Committee. Pulmonary-hepatic vascular disorders (PHD). Eur Respir J 2004;24:861-880.

4. Chang SC, Chang HI, Chen FJ, Shiao GM, Wang SS, Lee SD. Therapeutic effects of diuretics and paracentesis on lung function in patients with non-alcoholic cirrhosis and tense ascites. J Hepatol 1997;26:833-838.

5. Soulaidopoulos S, Cholongitas E, Giannakoulas G, Vlachou M, Goulis I. Review article: Update on current and emergent data on hepatopulmonary syndrome. World J Gastroenterol 2018;24:12851298.

6. Hoeper MM, Krowka MJ, Strassburg CP. Portopulmonary hypertension and hepatopulmonary syndrome. Lancet 2004;363:1461-1468.

7. Raevens S, Geerts A, Van Steenkiste C, Verhelst X, Van Vlierberghe H, Colle I. Hepatopulmonary syndrome and portopulmonary hypertension: recent knowledge in pathogenesis and overview of clinical assessment. Liver Int 2015;35:1646-1660.

8. Grilo I, Pascasio JM, López-Pardo FJ, et al. Hepatopulmonary syndrome: which blood gas analysis criteria and position should we use for diagnosis? Rev Esp Enferm Dig 2017;109:843-849.

9. Krowka MJ. Hepatopulmonary syndrome: recent literature (1997 to 1999) and implications for liver transplantation. Liver Transpl 2000;6:S31-S35.

10. Schenk P, Fuhrmann V, Madl C, et al. Hepatopulmonary syndrome: prevalence and predictive value of various cut offs for arterial oxygenation and their clinical consequences. Gut 2002;51:853-859.

11. Stoller JK, Lange PA, Westveer MK, Carey WD, Vogt D, Henderson JM. Prevalence and reversibility of the hepatopulmonary syndrome after liver transplantation. The Cleveland Clinic experience. West J Med 1995;163:133-138.

12. Zhang J, Fallon MB. Hepatopulmonary syndrome: update on pathogenesis and clinical features. Nat Rev Gastroenterol Hepatol 2012;9:539-549.

13. Younis I, Sarwar S, Butt Z, Tanveer S, Qaadir A, Jadoon NA. Clinical characteristics, predictors, and survival among patients with hepatopulmonary syndrome. Ann Hepatol 2015;14:354-360.

14. Kim BJ, Lee SC, Park SW, et al. Characteristics and prevalence of intrapulmonary shunt detected by contrast echocardiography with harmonic imaging in liver transplant candidates. Am J Cardiol 2004;94:525-528.

15. Rodriguez-Roisin R, Roca J, Agusti AG, Mastai R, Wagner PD, Bosch J. Gas exchange and pulmonary vascular reactivity in patients with liver cirrhosis. Am Rev Respir Dis 1987;135:10851092.

16. Katsuta Y, Honma H, Zhang XJ, et al. Pulmonary blood transit time and impaired arterial oxygenation in patients with chronic liver disease. J Gastroenterol 2005;40:57-63.

17. Iwakiri Y, Groszmann RJ. The hyperdynamic circulation of chronic liver diseases: From the patient to the molecule. Hepatology 
2006;43(2 Suppl 1):S121-S131.

18. Schraufnagel DE, Kay JM. Structural and pathologic changes in the lung vasculature in chronic liver disease. Clin Chest Med 1996;17:1-15.

19. Martínez GP, Barberà JA, Visa J, et al. Hepatopulmonary syndrome in candidates for liver transplantation. J Hepatol 2001;34:651-657.

20. Berthelot P, Walker JG, Sherlock S, Reid L. Arterial changes in the lungs in cirrhosis of the liver-lung spider nevi. $N$ Engl J Med 1966;274:291-298.

21. Krowka MJ. Hepatopulmonary syndrome versus portopulmonary hypertension: distinctions and dilemmas. Hepatology 1997;25: 1282-1284.

22. Bolognesi M, Di Pascoli M, Verardo A, Gatta A. Splanchnic vasodilation and hyperdynamic circulatory syndrome in cirrhosis. World J Gastroenterol 2014;20:2555-2563.

23. Cremona G, Higenbottam TW, Mayoral V, et al. Elevated exhaled nitric oxide in patients with hepatopulmonary syndrome. Eur Respir J 1995;8:1883-1885.

24. Rolla G, Brussino L, Colagrande P, et al. Exhaled nitric oxide and impaired oxygenation in cirrhotic patients before and after liver transplantation. Ann Intern Med 1998; 129:375-378.

25. Ling Y, Zhang J, Luo B, et al. The role of endothelin-1 and the endothelin $\mathrm{B}$ receptor in the pathogenesis of hepatopulmonary syndrome in the rat. Hepatology 2004;39:1593-1602.

26. Sztrymf B, Libert JM, Mougeot C, et al. Cirrhotic rats with bacterial translocation have higher incidence and severity of hepatopulmonary syndrome. J Gastroenterol Hepatol 2005;20:1538-1544.

27. Zhang M, Luo B, Chen S-J, Abrams GA, Fallon MB. Endothelin-1 stimulation of endothelial nitric oxide synthase in the pathogenesis of hepatopulmonary syndrome. Am J Physiol 1999;277:G944-G952.

28. Luo B, Tang L, Wang Z, et al. Cholangiocyte endothelin 1 and transforming growth factor betal production in rat experimental hepatopulmonary syndrome. Gastroenterology 2005;129:682-695.

29. Carter EP, Hartsfield CL, Miyazono M, Jakkula M, Morris KG, McMurtry IF. Regulation of heme oxygenase- 1 by nitric oxide during hepatopulmonary syndrome. Am J Physiol Lung Cell Mol Physiol 2002;283:L346-L353.

30. Roberts KE, Kawut SM, Krowka MJ, et al. Genetic risk factors for hepatopulmonary syndrome in patients with advanced liver disease. Gastroenterology; 2010;139:130-9e24.

31. Thenappan T, Goel A, Marsboom G, et al. A central role for CD68(+) macrophages in hepatopulmonary syndrome. Reversal by macrophage depletion. Am J Respir Crit Care Med 2011;183:10801091.

32. Soulaidopoulos S, Goulis I, Giannakoulas G, et al. Hepatopulmonary syndrome is associated with the presence of hepatocellular carcinoma in patients with decompensated cirrhosis. Ann Gastroenterol 2017;30:225-231.

33. Chang CC, Chuang CL, Lee FY, et al. Sorafenib treatment improves hepatopulmonary syndrome in rats with biliary cirrhosis. Clin Sci (Lond) 2013;124:457-466.

34. Kawut SM, Ellenberg SS, Krowka MJ, et al. Sorafenib in hepatopulmonary syndrome: a randomized, double-blind, placebo-controlled trial. Liver Transpl 2019;25:1155-1164.

35. Lejealle C, Paradis V, Bruno O, et al. Evidence for an association between intrahepatic vascular changes and the development of hepatopulmonary syndrome. Chest 2019;155:123-136.

36. Ma C, Crippin JS, Chapman WC, et al. Parenchymal alterations in cirrhotic livers in patients with hepatopulmonary syndrome or portopulmonary hypertension. Liver Transpl 2013;19:741-750.

37. Fussner LA, Krowka MJ. Current approach to the diagnosis and management of portopulmonary hypertension. Curr Gastroenterol Rep 2016;18:29.

38. Krowka MJ, Wiseman GA, Burnett OL, et al. Hepatopulmonary syndrome: a prospective study of relationships between severity of liver disease, $\mathrm{PaO}(2)$ response to $100 \%$ oxygen, and brain uptake after (99m)Tc MAA lung scanning. Chest 2000;118:615-624.
39. Anand AC, Mukherjee D, Rao KS, Seth AK. Hepatopulmonary syndrome: prevalence and clinical profile. Indian J Gastroenterol 2001;20:24-27.

40. Krowka MJ, Dickson ER, Cortese DA. Hepatopulmonary syndrome. Clinical observations and lack of therapeutic response to somatostatin analogue. Chest 1993;104:515-521.

41. Singh C, Sager JS. Pulmonary complications of cirrhosis. Med Clin North Am 2009;93:871-883, viii.

42. Mohammad Alizadeh AH, Fatemi SR, Mirzaee V, et al. Clinical features of hepatopulmonary syndrome in cirrhotic patients. World J Gastroenterol 2006;12:1954-1956.

43. Fallon MB, Krowka MJ, Brown RS, et al; Pulmonary Vascular Complications of Liver Disease Study Group. Impact of hepatopulmonary syndrome on quality of life and survival in liver transplant candidates. Gastroenterology 2008;135:1168-1175.

44. Deibert P, Allgaier HP, Loesch S, et al. Hepatopulmonary syndrome in patients with chronic liver disease: role of pulse oximetry. $B M C$ Gastroenterol 2006;6:15.

45. Martin P, DiMartini A, Feng S, Brown R Jr, Fallon M. Evaluation for liver transplantation in adults: 2013 practice guideline by the American Association for the Study of Liver Diseases and the American Society of Transplantation. Hepatology 2014;59:11441165.

46. Forde KA, Fallon MB, Krowka MJ, et al; Pulmonary Vascular Complications of Liver Disease 2 Study Group. Pulse oximetry is insensitive for detection of hepatopulmonary syndrome in patients evaluated for liver transplantation. Hepatology 2019;69:270-281.

47. Kochar R, Tanikella R, Fallon MB. Serial pulse oximetry in hepatopulmonary syndrome. Dig Dis Sci 2011;56:1862-1868.

48. Abrams GA, Jaffe CC, Hoffer PB, Binder HJ, Fallon MB. Diagnostic utility of contrast echocardiography and lung perfusion scan in patients with hepatopulmonary syndrome. Gastroenterology 1995; 109:1283-1288.

49. Soliman OII, Geleijnse ML, Meijboom FJ, et al. The use of contrast echocardiography for the detection of cardiac shunts. Eur $J$ Echocardiogr 2007;8:S2-S12.

50. Zhao H, Tsauo J, Zhang X, et al. Pulmonary transit time derived from pulmonary angiography for the diagnosis of hepatopulmonary syndrome. Liver Int 2018;38:1974-1981.

51. Barzilai B, Waggoner AD, Spessert C, Picus D, Goodenberger D. Two-dimensional contrast echocardiography in the detection and follow-up of congenital pulmonary arteriovenous malformations. Am J Cardiol 1991;68:1507-1510.

52. Velthuis S, Buscarini E, Gossage JR, Snijder RJ, Mager JJ, Post MC. Clinical implications of pulmonary shunting on saline contrast echocardiography. J Am Soc Echocardiogr 2015;28:255-263.

53. van Gent MWF, Post MC, Snijder RJ, et al. Grading of pulmonary right-to-left shunt with transthoracic contrast echocardiography: does it predict the indication for embolotherapy? Chest 2009;135:1288-1292.

54. Zamirian M, Aslani A, Shahrzad S. Left atrial volume: a novel predictor of hepatopulmonary syndrome. Am J Gastroenterol 2007;102:1392-1396.

55. Fragaki M, Sifaki-Pistolla D, Samonakis DN, et al. Screening for hepatopulmonary syndrome in cirrhotic patients using technetium 99m-macroaggregated albumin perfusion lung scan (Tc-MAA). $J$ Clin Gastroenterol 2018;52:828-834.

56. El-Shabrawi MH, Omran S, Wageeh S, et al. (99m)Technetiummacroaggregated albumin perfusion lung scan versus contrast enhanced echocardiography in the diagnosis of the hepatopulmonary syndrome in children with chronic liver disease. Eur J Gastroenterol Hepatol 2010;22:1006-1012.

57. Mimidis KP, Vassilakos PI, Mastorakou AN, et al. Evaluation of contrast echocardiography and lung perfusion scan in detecting intrapulmonary vascular dilatation in normoxemic patients with early liver cirrhosis. Hepatogastroenterology 1998;45:2303-2307. 
58. Raevens S, Fallon MB. Potential clinical targets in hepatopulmonary syndrome: lessons from experimental models. Hepatology 2018;68:2016-2028.

59. Söderman C, Juhlin-Dannfelt A, Lagerstrand L, Eriksson LS. Ventilation-perfusion relationships and central haemodynamics in patients with cirrhosis. Effects of a somatostatin analogue. J Hepatol 1994;21:52-57.

60. Chang CC, Chuang CL, Lee FY, et al. Sorafenib treatment improves hepatopulmonary syndrome in rats with biliary cirrhosis. Clin Sci (Lond) 2013;124:457-466.

61. Ko MT, Huang HC, Lee WS, et al. Metformin reduces intrahepatic fibrosis and intrapulmonary shunts in biliary cirrhotic rats. J Chin Med Assoc 2017;80:467-475.

62. Tsai H-C, Yang Y-Y. Pioglitazone decrease intrapulmonary shunt in biliary cirrhotic rats with hepatopulmonary syndrome. J Chinese Med Assoc 2017;80:679-680.

63. Raevens S, Geerts A, Paridaens A, et al. Placental growth factor inhibition targets pulmonary angiogenesis and represents a therapy for hepatopulmonary syndrome in mice. Hepatology 2018;68:634-651.

64. Fernandez M. Placental growth factor: New treatment target bringing hope for hepatopulmonary syndrome. Hepatology 2018;68:404-407.

65. Allgaier HP, Haag K, Ochs A, et al. Hepato-pulmonary syndrome: successful treatment by transjugular intrahepatic portosystemic stent-shunt (TIPS). J Hepatol 1995;23:102.

66. Paramesh AS, Husain SZ, Shneider B, et al. Improvement of hepatopulmonary syndrome after transjugular intrahepatic portasystemic shunting: case report and review of literature. Pediatr Transplant 2003;7:157-162.

67. Poterucha JJ, Krowka MJ, Dickson ER, Cortese DA, Stanson AW, Krom RA. Failure of hepatopulmonary syndrome to resolve after liver transplantation and successful treatment with embolotherapy. Hepatology 1995;21:96-100.

68. Rodriguez-Roisin R, Krowka MJ. Is severe arterial hypoxaemia due to hepatic disease an indication for liver transplantation? A new therapeutic approach. Eur Respir J 1994;7:839-842.

69. Swanson KL, Wiesner RH, Krowka MJ. Natural history of hepatopulmonary syndrome: Impact of liver transplantation. Hepatology 2005;41:1122-1129.

70. Pascasio JM, Grilo I, López-Pardo FJ, et al. Prevalence and severity of hepatopulmonary syndrome and its influence on survival in cirrhotic patients evaluated for liver transplantation. Am J Transplant 2014;14:1391-1399.

71. Schiffer E, Majno P, Mentha G, et al. Hepatopulmonary syndrome increases the postoperative mortality rate following liver transplantation: a prospective study in 90 patients. Am J Transplant 2006;6:1430-1437.

72. Goldberg DS, Krok K, Batra S, Trotter JF, Kawut SM, Fallon MB. Impact of the hepatopulmonary syndrome MELD exception policy on outcomes of patients after liver transplantation: an analysis of the UNOS database. Gastroenterology 2014;146:12561265.e1.

73. Iyer VN, Swanson KL, Cartin-Ceba R, et al. Hepatopulmonary syndrome: favorable outcomes in the MELD exception era. Hepatology 2013;57:2427-2435.

74. European Association for the Study of the Liver. EASL Clinical Practice Guidelines for the management of patients with decompensated cirrhosis. J Hepatol 2018;69:406-460.

75. Martin P, DiMartini A, Feng S, Brown J R, Fallon M. Evaluation for liver transplantation in adults: 2013 practice guideline by the AASLD and the American Society of Transplantation. Hepatology 2014;59:1144-1165.

76. Mandell MS. Hepatopulmonary syndrome and portopulmonary hypertension in the model for end-stage liver disease (MELD) era. Liver Transpl 2004;10(10 Suppl 2):S54-S58.

77. Krowka MJ, Fallon MB, Kawut SM, et al. International Liver
Transplant Society Practice Guidelines. Transplantation 2016;100:1440-1452.

78. Simonneau G, Robbins IM, Beghetti M, et al. Updated clinical classification of pulmonary hypertension. I Am Coll Cardiol 2009;54:S43-S54.

79. Galiè N, Humbert M, Vachiery JL, et al. 2015 ESC/ERS Guidelines for the diagnosis and treatment of pulmonary hypertension: The Joint Task Force for the Diagnosis and Treatment of Pulmonary Hypertension of the European Society of Cardiology (ESC) and the European Respiratory Society (ERS): Endorsed by: Association for European Paediatric and Congenital Cardiology (AEPC), International Society for Heart and Lung Transplantation (ISHLT). Eur Respir J 2015;46:903-975.

80. Budhiraja R, Hassoun PM. Portopulmonary hypertension: a tale of two circulations. Chest 2003;123:562-576.

81. Hadengue A, Benhayoun MK, Lebrec D, Benhamou JP. Pulmonary hypertension complicating portal hypertension: prevalence and relation to splanchnic hemodynamics. Gastroenterology 1991; 100:520-528.

82. Colle IO, Moreau R, Godinho E, et al. Diagnosis of portopulmonary hypertension in candidates for liver transplantation: a prospective study. Hepatology 2003;37:401-409.

83. Krowka MJ, Swanson KL, Frantz RP, McGoon MD, Wiesner RH. Portopulmonary hypertension: Results from a 10-year screening algorithm. Hepatology 2006;44:1502-1510.

84. Sithamparanathan S, Nair A, Thirugnanasothy L, et al. Survival in portopulmonary hypertension: outcomes of the United Kingdom National Pulmonary Arterial Hypertension Registry. J Heart Lung Transplant 2017;36:770-779.

85. Kawut SM, Krowka MJ, Trotter JF, et al; Pulmonary Vascular Complications of Liver Disease Study Group. Clinical risk factors for portopulmonary hypertension. Hepatology 2008;48:196-203.

86. Kawut SM, Krowka MJ, Trotter JF, et al; Pulmonary Vascular Complications of Liver Disease Study Group. Clinical risk factors for portopulmonary hypertension. Hepatology 2008;48:196-203.

87. Humbert M, Sitbon O, Chaouat A, et al. Pulmonary arterial hypertension in France: results from a national registry. Am J Respir Crit Care Med 2006;173:1023-1030.

88. Krowka MJ, Edwards WD. A spectrum of pulmonary vascular pathology in portopulmonary hypertension. Liver Transpl 2000;6:241-242.

89. Pellicelli AM, Barbaro G, Puoti C, et al. Plasma cytokines and portopulmonary hypertension in patients with cirrhosis waiting for orthotopic liver transplantation. Angiology 2010;61:802-806.

90. Bartolome SD. Portopulmonary hypertension: Diagnosis, clinical features, and medical therapy. Clinical Liver Disease 2014;4: 42-45.

91. Liberal R, Grant CR, Baptista R, Macedo G. Porto-pulmonary hypertension: a comprehensive review. Clin Res Hepatol Gastroenterol 2015;39:157-167.

92. Gupta S, Krowka MJ. Hepatopulmonary syndrome. CMAJ 2018; 190:223.

93. Benjaminov FS, Prentice M, Sniderman KW, Siu S, Liu P, Wong F. Portopulmonary hypertension in decompensated cirrhosis with refractory ascites. Gut 2003;52:1355-1362.

94. Robalino BD, Moodie DS. Association between primary pulmonary hypertension and portal hypertension: analysis of its pathophysiology and clinical, laboratory and hemodynamic manifestations. J Am Coll Cardiol 1991;17:492-498.

95. Nayak RP, Li D, Matuschak GM. Portopulmonary hypertension. Curr Gastroenterol Rep 2009;11:56-63.

96. Porres-Aguilar M, Zuckerman MJ, Figueroa-Casas JB, Krowka MJ. Portopulmonary hypertension: state of the art. Ann Hepatol 2008;7:321-330.

97. Koulava A, Sannani A, Levine A, et al. Diagnosis, treatment and management of orthotopic liver transplant candidates with 
portopulmonary hypertension. Cardiol Rev 2018;26:169-176.

98. Galiè N, Humbert M, Vachiery JL, et al; ESC Scientific Document Group. 2015 ESC/ERS Guidelines for the diagnosis and treatment of pulmonary hypertension: The Joint Task Force for the Diagnosis and Treatment of Pulmonary Hypertension of the European Society of Cardiology (ESC) and the European Respiratory Society (ERS): Endorsed by: Association for European Paediatric and Congenital Cardiology (AEPC), International Society for Heart and Lung Transplantation (ISHLT). Eur Heart J 2016;37:67-119.

99. Bossone E, D’Andrea A, D'Alto M, et al. Echocardiography in pulmonary arterial hypertension: from diagnosis to prognosis. $J$ Am Soc Echocardiogr 2013;26:1-14.

100. Kim W, Krowka MJ, Plevak DJ, et al. Accuracy of Doppler echocardiography in the assessment of pulmonary hypertension in liver transplant candidates. Liver Transpl 2000;6:453-458.

101. Badesch DB, Champion HC, Sanchez MA, et al. Diagnosis and assessment of pulmonary arterial hypertension. J Am Coll Cardiol 2009;54:S55-S66.

102. Garg A, Armstrong WF. Echocardiography in liver transplant candidates. JACC Cardiovasc Imaging 2013;6:105-119.

103. Cartin-Ceba R, Halank M, Ghofrani HA, et al. Riociguat treatment for portopulmonary hypertension: a subgroup analysis from the PATENT-1/-2 studies. Pulm Circ 2018;8:2045894018769305.

104. Hoeper MM, Seyfarth HJ, Hoeffken G, et al. Experience with inhaled iloprost and bosentan in portopulmonary hypertension. Eur Respir J 2007;30:1096-1102.

105. Savale L, Magnier R, Le Pavec J, et al. Efficacy, safety and pharmacokinetics of bosentan in portopulmonary hypertension. Eur Respir J 2013;41:96-103.

106. Cartin-Ceba R, Swanson K, Iyer V, Wiesner RH, Krowka MJ. Safety and efficacy of ambrisentan for the treatment of portopulmonary hypertension. Chest 2011;139:109-114.

107. Boswell-Smith V, Spina D, Page CP. Phosphodiesterase inhibitors. Br J Pharmacol 2006;147(Suppl 1):S252-S257.

108. Reichenberger F, Voswinckel R, Steveling E, et al. Sildenafil treatment for portopulmonary hypertension. Eur Respir $J$ 2006;28:563-567.

109. Krowka MJ, Frantz RP, McGoon MD, Severson C, Plevak DJ, Wiesner RH. Improvement in pulmonary hemodynamics during intravenous epoprostenol (prostacyclin): A study of 15 patients with moderate to severe portopulmonary hypertension. Hepatology 1999;30:641-648.

110. Schroeder RA, Rafii AA, Plotkin JS, Johnson LB, Rustgi VK, Kuo PC. Use of aerosolized inhaled epoprostenol in the treatment of portopulmonary hypertension. Transplantation 2000;70:548-550.

111. Melgosa MT, Ricci GL, García-Pagan JC, et al. Acute and longterm effects of inhaled iloprost in portopulmonary hypertension. Liver Transpl 2010;16:348-356.

112. Touma W, Nayak RP, Hussain Z, Bacon BR, Kudva GC. Epoprostenol-induced hypersplenism in portopulmonary hypertension. Am J Med Sci 2012;344:345-349.

113. AbuHalimeh B, Krowka MJ, Tonelli AR. Treatment barriers in portopulmonary hypertension. Hepatology 2019;69:431-443.

114. Legros L, Chabanne $\mathrm{C}$, Camus $\mathrm{C}$, et al. Oral pulmonary vasoactive drugs achieve hemodynamic eligibility for liver transplantation in portopulmonary hypertension. Dig Liver Dis 2017;49:301-307.

115. Faisal M, Siddiqi F, Alkaddour A, Bajwa AA, Shujaat A. Effect of PAH specific therapy on pulmonary hemodynamics and six-minute walk distance in portopulmonary hypertension: a systematic review and meta-analysis. Pulm Med 2014;2014:528783.

116. Navasa M, Bosch J, Reichen J, et al. Effects of verapamil on hepatic and systemic hemodynamics and liver function in patients with cirrhosis and portal hypertension. Hepatology 1988;8:850-854.

117. Galiè N, Corris PA, Frost A, et al. Updated treatment algorithm of pulmonary arterial hypertension. J Am Coll Cardiol 2013;62(25 Suppl):D60-D72.
118. Provencher S, Herve P, Jais X, et al. Deleterious effects of betablockers on exercise capacity and hemodynamics in patients with portopulmonary hypertension. Gastroenterology 2006;130:120-126.

119. Van der Linden $P$, Le Moine $O$, Ghysels M, Ortinez M, Devière J. Pulmonary hypertension after transjugular intrahepatic portosystemic shunt: effects on right ventricular function. Hepatology 1996;23:982-987.

120. Kawut SM, Taichman DB, Ahya VN, et al. Hemodynamics and survival of patients with portopulmonary hypertension. Liver Transpl 2005;11:1107-1111.

121. Vionnet J, Yerly P, Aubert J-D, et al. Management of severe portopulmonary hypertension with dual oral therapy before liver transplantation. Transplantation 2018;102:e194.

122. Swanson KL, Wiesner RH, Nyberg SL, Rosen CB, Krowka MJ. Survival in portopulmonary hypertension: Mayo Clinic experience categorized by treatment subgroups. Am J Transplant 2008;8:2445-2453.

123. Le Pavec J, Souza R, Herve P, et al. Portopulmonary hypertension: survival and prognostic factors. Am J Respir Crit Care Med. 2008;178(6):637-643.

124. Li J, Zhuang Q, Zhang X, Zheng Y, et al. Prevalence and prognosis of portopulmonary hypertension in 223 liver transplant recipients. Can Respir J 2018;2018:9629570.

125. Savale L, Sattler C, Coilly A, et al. Long-term outcome in liver transplantation candidates with portopulmonary hypertension. Hepatology 2017;65:1683-1692.

126. Huang B, Shi Y, Liu J, et al. The early outcomes of candidates with portopulmonary hypertension after liver transplantation. BMC Gastroenterol 2018;18:79.

127. Reymond M, Barbier L, Salame E, et al. Does portopulmonary hypertension impede liver transplantation in cirrhotic patients? A French multicentric retrospective study. Transplantation 2018;102:616-622.

128. DuBrock HM, Goldberg DS, Sussman NL, et al. Predictors of waitlist mortality in portopulmonary hypertension. Transplantation 2017;101:1609-1615.

129. Krowka M, PlevakDJ, Findlay JY, Rosen CB, Wiesner RH, Krom RA. Pulmonary hemodynamics and perioperative cardiopulmonaryrelated mortality in patients with portopulmonary hypertension undergoing liver transplantation. Liver Transpl 2000; 6:443-450.

130. Krowka MJ, Mandell MS, Ramsay MAE, et al. Hepatopulmonary syndrome and portopulmonary hypertension: a report of the multicenter liver transplant database. Liver Transpl 2004;10:174-182.

131. Krowka MJ, Heimbach JK. Portopulmonary hypertension and liver transplantation: A duo in question. Liver Transpl 2016;22:1633-1634.

132. Light RW. The Light criteria: the beginning and why they are useful 40 years later. Clin Chest Med 2013;34:21-26.

133. Machicao VI, Balakrishnan M, Fallon MB. Pulmonary complications in chronic liver disease. Hepatology 2014;59:1627-1637.

134. Lv Y, Han G, Fan D. Hepatic hydrothorax. Ann Hepatol 2018;17:33-46.

135. Alonso JC. Pleural effusion in liver disease. Semin Respir Crit Care Med 2010;31:698-705.

136. Eisenberg B, Velchik MG, Alavi A. Pleuroperitoneal communication in a patient with right pleural effusion and ascites diagnosed by technetium-99m sulfur colloid imaging. Clin Nucl Med 1988;13:99-101.

137. Kim JS, Kim CW, Nam HS, Cho JH, Ryu JS, Lee HL. Hepatic hydrothorax without ascites as the first sign of liver cirrhosis. Respirol Case Rep 2015;4:16-18.

138. Badillo R, Rockey DC. Hepatic hydrothorax: Clinical features, management, and outcomes in 77 patients and review of the literature. Medicine (Baltimore) 2014;93:135-142.

139. Allam NA. Spontaneous bacterial empyema in liver cirrhosis: an underdiagnosed pleural complication. Saudi J Gastroenterol 
2008; 14:43-45.

140. Xiol X, Castellví JM, Guardiola J, et al. Spontaneous bacterial empyema in cirrhotic patients: a prospective study. Hepatology 1996;23:719-723.

141. Castellote J, Lopez C, Gornals J, Domingo A, Xiol X. Use of reagent strips for the rapid diagnosis of spontaneous bacterial empyema. J Clin Gastroenterol 2005;39:278-281.

142. Singh A, Bajwa A, Shujaat A. Evidence-based review of the management of hepatic hydrothorax. Respiration 2013;86:155-173.

143. Sese E, Xiol X, Castellote J, Rodríguez-Fariñas E, Tremosa G. Low complement levels and opsonic activity in hepatic hydrothorax: its relationship with spontaneous bacterial empyema. J Clin Gastroenterol 2003;36:75-77.

144. Porcel JM. Management of refractory hepatic hydrothorax. Curr Opin Pulm Med 2014;20:352-357.

145. Conklin LD, Estrera AL, Weiner MA, Reardon PR, Reardon MJ. Transjugular intrahepatic portosystemic shunt for recurrent hepatic hydrothorax. Ann Thorac Surg 2000;69:609-611.

146. Ditah IC, Al Bawardy BF, Saberi B, Ditah C, Kamath PS.
Transjugular intrahepatic portosystemic stent shunt for medically refractory hepatic hydrothorax: A systematic review and cumulative meta-analysis. World J Hepatol 2015;7:17971806.

147. Dhanasekaran R, West JK, Gonzales PC, et al. Transjugular intrahepatic portosystemic shunt for symptomatic refractory hepatic hydrothorax in patients with cirrhosis. Am J Gastroenterol 2010;105:635-641.

148. Parker R, Armstrong MJ, Rowe IA, Houlihan DD. Estimated short-term mortality following TIPS insertion for patients with hepatic hydrothorax. Am J Gastroenterol 2013;108:1806-1807.

149. Light RW. New treatment for hepatic hydrothorax? Ann Am Thorac Soc 2016;13:773-774.

150. Cerfolio RJ, Bryant AS. Efficacy of video-assisted thoracoscopic surgery with talc pleurodesis for porous diaphragm syndrome in patients with refractory hepatic hydrothorax. Ann Thorac Surg 2006;82:457-459.

151. Tu CY, Chen CH. Spontaneous bacterial empyema. Curr Opin Pulm Med 2012;18:355-358. 